\title{
KESETARAAN GENDER UNTUK PEREMPUAN KORBAN KEKERASAN DALAM RUMAH TANGGA
}

\author{
Dudi Badruzaman $^{*(a, 1)}$, Ahmad Ropei ${ }^{(b, 2)}$. \\ aSTAI Sabili Bandung \\ bSTAI Miftahul Huda Subang \\ E-Mail: ${ }^{1}$ badruzaman.dudi@yahoo.com, ${ }^{2}$ ahmadropei88@gmail.com \\ E-Mail: 'badruzaman.dudi@yahoo.com (Corresponding Author)
}

\begin{tabular}{|c|c|}
\hline Article Info & bstract \\
\hline $\begin{array}{l}\text { Article History } \\
\text { Received: June } 2020 \\
\text { Revised: June } 2020 \\
\text { Published: June } 2020\end{array}$ & $\begin{array}{l}\text { Discrimination against women is a problem that often occurs } \\
\text { in almost all levels of society, even in most parts of the world. } \\
\text { This study aims to determine the understanding of gender } \\
\text { equality and how the results of the analysis to reduce violence } \\
\text { and provide justice for women in Indonesia. The method used } \\
\text { is field research by collecting data, conducting interviews, and } \\
\text { analyzing documentation data. Gender is not a movement that } \\
\text { fights for women's destiny, on the contrary, it is a movement } \\
\text { that erases maternal instincts from women by separating the } \\
\text { natural and non-natural roles. Thus, gender is not just a term } \\
\text { but a doctrine feminist that erases human nature. }\end{array}$ \\
\hline Informasi Artikel & Abstrak \\
\hline $\begin{array}{l}\text { Sejarah Artikel } \\
\text { Diterima: Juni } 2020 \\
\text { Direvisi: Juni } 2020 \\
\text { Dipublikasi: Juni } 2020\end{array}$ & $\begin{array}{l}\text { Diskriminasi terhadap perempuan merupakan masalah yang } \\
\text { kerapkali terjadi di hampir seluruh lapisan kelompok } \\
\text { masyarakat, bahkan di sebagian besar belahan dunia } \\
\text { sekalipun. Penelitian ini bertujuan untuk mengetahui paham } \\
\text { kesetaraan gender dan bagaimana hasil analisis dalam } \\
\text { rangka mengurangi kekerasan dan memberi keadilan bagi } \\
\text { perempuan di Indonesia. Metode yang di gunakan adalah } \\
\text { penelitian lapangan dengan pengumpulan data, melakukan } \\
\text { wawancara dan analisis terhadap data dokumentasi. Gender } \\
\text { bukanlah gerakan yang memperjuangkan nasib perempuan, } \\
\text { sebaliknya, ia merupakan gerakan yang menghapus naluri } \\
\text { keibuan dari perempuan dengan memisahkan peran yang } \\
\text { kodrati dan yang bukan kodrati, Sehingga, gender bukan } \\
\text { sekedar istilah tetapi sebuah doktrin feminis yang } \\
\text { menghapuskan fitrah manusia. }\end{array}$ \\
\hline \multicolumn{2}{|c|}{$\begin{array}{l}\text { Sitasi: Badruzaman, D. (2020). "Kesetaraan Gender Untuk Perempuan Korban Kekerasan dalam } \\
\text { Rumah Tangga". Al-Ihkam: Jurnal Hukum Keluarga Jurusan Ahwal al-Syakhshiyyah Fakultas } \\
\text { Syariah IAIN Mataram. 12(1), 1-14 }\end{array}$} \\
\hline
\end{tabular}

\section{PENDAHULUAN}

Salah satu persoalan hukum dalam masyarakat yang masih mengganjal dan menjadi tugas besar pemerintah untuk dapat diselesaikan adalah masalah kekerasan terhadap perempuan, kenyataan seperti ini tidak hanya terjadi di negara-negara berkembang seperti Indonesia, tetapi juga terjadi di negara-negara maju seperti Eropa Barat dan Amerika Serikat. Berbagai upaya ditempuh untuk mengangkat derajat dan posisi perempuan agar setara dengan laki-laki melalui berbagai institusi, baik yang formal maupun yang nonformal.

Gender merupakan konsep yang mengkaji tentang perbedaan antara laki-laki dan perempuan sebagai hasil dari pembentukan kepribadian yang berasal dari masyarakat (kondisi sosial, adat-istiadat dan kebudayaan yang berlaku). Gender dalam arti ini adalah suatu bentuk rekayasa masyarakat (social contructions), bukannya sesuatu 
yang bersifat kodrati. ${ }^{1}$ Adapun konsep kesetaraan gender yang selalu mengemuka adalah konsep analisis yang digunakan untuk mengidentifikasi peran, relasi, atribut, peringkat, karakteristik, serta perbedaan antara laki-laki dan perempuan dalam rangka menempatkan posisi setara antara laki-laki dan perempuan untuk mewujudkan tatanan sosial masyarakat yang lebih egaliter.

Gender bisa dikategorikan sebagai perangkat operasional dalam melakukan measure (pengukuran) terhadap persoalan laki-laki dan perempuan terutama yang terkait dengan pembagian peran dalam masyarakat yang dikonstruksi oleh masyarakat itu sendiri. ${ }^{2}$ Gender bukan hanya ditujukan kepada perempuan semata, tetapi juga kepada laki-laki. Hanya saja, yang dianggap mengalami posisi termarginalkan sekarang adalah pihak perempuan, maka perempuanlah yang lebih ditonjolkan dalam pembahasan untuk mengejar kesetaraan gender yang telah diraih oleh laki-laki beberapa tingkat dalam peran sosial, terutama di bidang pendidikan. Karena bidang inilah diharapkan dapat mendorong perubahan kerangka berpikir, bertindak, dan berperan dalam berbagai segmen kehidupan sosial. Bentuk kekerasan terhadap perempuan yang paling sering terjadi dan dilaporkan sebagai kasus hukum adalah kekerasan dalam rumah tangga atau yang lebih dikenal dengan KDRT wujudnya dapat berupa kekerasan verbal, fisik, psikis, hingga seksual, baik itu secara disadari maupun tidak.

KOMNAS Perempuan Indonesia mencatat pada tahun 2011 terdapat 113.878 kasus KDRT yang ditangani oleh lembaga pengada layanan atau 95,61 persen dari total kasus kekerasan yang terjadi pada perempuan (Catatan Tahunan KOMNAS Perempuan 2011). Perlu digaris bawahi bahwa jumlah ini hanya merepresentasikan jumlah kasus kekerasan yang terlaporkan belum termasuk kasuskasus yang tidak terlaporkan, banyaknya jumlah kekerasan yang terjadi dan persentase yang besar dalam kasus KDRT menjadikan isu ini menarik untuk dibahas lebih mendalam.

Lebih jauh menanggapi persoalan ini pemerintah bukannya tidak mengambil langkah yang serius, Produk perundang-undangan seperti UU No. 7 Tahun 1984 yang menjadi langkah pemerintah dalam meratifikasi CEDAW dan UU No. 23 Tahun 2004 yang mengatur tentang Penghapusan Kekerasan Dalam Rumah Tangga menunjukkan komitmen pemerintah untuk melindungi hak perempuan.

Namun setelah lebih dari 28 tahun ratifikasi CEDAW dan hampir 10 tahun UU Penghapusan KDRT berlaku, kasus KDRT nyatanya terus terjadi tiap tahunnya, jika hukum yang dimaksudkan untuk mengatur masyarakat pada umumnya dan memberi perlindungan serta keadilan bagi perempuan pada khususnya tetap belum dapat memberi pengaruh yang signifikan pada realita kasus KDRT berarti ada masalah serius yang perlu ditinjau dan ditindaklanjuti. Bias gender yang ada dalam keluarga ataupun masyarakat secara luas bukan hanya perjuangan yang harus dilakukan oleh kaum perempuan saja, akan tetapi hal ini juga akan sangat tergantung pada kekuatan institusi-institusi sosial yang ada di masyarakat, sebab perempuan

${ }^{1}$ Ruth Roded, "Jewish and Islamic Religious Feminist Exegesis of the Sacred Books: Adam, Woman and Gender," Nashim: A Journal of Jewish Women's Studies \& Gender Issues, No. 29, (Bloomington:Women's Torah Study Indiana University Press, 2015), 61.

2Julia Cleves Mosse, Gender dan Pembangunan, (Yogyakarta: Pustaka Pelajar,2010), 3. 
dalam arti institusi merupakan bagian dari masyarakat. Dengan kata lain, jika perjuangan pembebasan ketertindasan perempuan bukan merupakan agenda perempuan saja, maka diperlukan emansipasi dan peran masyarakat secara luas. Penelitian ini fokus pada pembahasan tentang pemenuhan keadilan dan kesetaraan gender untuk perempuan korban kekerasan dalam rumah tangga. Tujuan penelitian ini diharapkan dapat menumbuhkan awareness atas isu kekerasan terhadap perempuan dalam studi akademis dan memberi penajaman analisis serta cara pandang atas isu ini.

\section{PEMBAHASAN}

\section{Kesetaraan Gender}

Memahami istilah gender bukanlah hal yang sederhana. Kata gender sendiri termasuk kosa kata baru sehingga pengertiannya tidak ditemukan dalam Kamus Besar Bahasa Indonesia. ${ }^{3}$ Istilah gender yang pertama kali dipahami sebagai perbedaan kelamin berasal dari bahasa latin genus yang berarti kelahiran, keluarga, atau bangsa. ${ }^{4}$ Sedang kata gender dalam istilah bahasa Indonesia berasal dari bahasa inggris, yaitu gender. Dalam Kamus Inggris Indonesia yang ditulis John M. Echols dan Hassan Shadily tertulis gender berarti "jenis kelamin." Namun pengertian secara bahasa ini mendapat penolakan dari kalangan feminis.

Bagi para feminis kata gender harus dipisahkan dari kata sex (jenis kelamin) yang menyifati manusia secara biologis. Istilah gender pertama kali diperkenalkan oleh Robert J Stoller ${ }^{6}$ untuk memisahkan pencirian manusia yang didasarkan pada pendefinisian yang bersifat sosial budaya dengan pendefinisian dari ciri-ciri biologis.

Berapa kerangka yang telah membangun serta mewarnai wacana ini. Pertama, gender sebagai gerakan, yaitu gerakan-gerakan keperempuanan (feminisme) yang berkembang sesuai ideologi yang dianut, seperti feminis liberal, feminis radikal, feminis sosialis marxis, dan lain-lain. Tahap inilah yang oleh kaum feminis disebut dengan gelombang pertama feminisme.

Kedua, gender sebagai diskursus kefilsafatan. Sasaran kajian filsafat adalah pola pikir manusia, sehingga objek kajian gender kali ini adalah pola pikir manusia tentang perempuan, bukan para perempuan itu sendiri. Diskursus kefilsafatan ini tidak bisa lepas dari semangat pemikiran post modern yang membawa tema besar semangat relativitas, dekonstruksi, rekonstruksi, dan pluralitas. Bagi para feminis masuknya persoalan gender ke dalam dikursus filsafat, menjadi tanda gerakan feminisme gelombang kedua.

Ketiga, gender dari isu sosial ke isu agama. Awalnya tuntutan kesetaraan gender yang disuarakan para feminis dibangun atas keprihatinan terhadap masalah sosial. Namun belakangan para feminis khususnya feminis liberal menuntut pembebasan kaum perempuan dari agama dan moralitasnya yang mereka anggap

33.

${ }^{3}$ Nasaruddin Umar, Argumen Kesetaraan Gender Perspektif al-Qur'an, (Jakarta: Paramadina, 2011),

${ }^{4}$ Little, William, The Shorter Oxford English Dictionery, (Oxford: University Press, 2012), 13.

5John M. Echols dan Hassan Shadily, Kamus Inggris Indonesia, (Jakarta: Gramedia, 1983), 265.

${ }^{6}$ Robert J. Stoller, Sex And Gender, (London:Karnac,2010), 9. 
buah dari agama patriaki atau agama kaum laki-laki. Sehingga tradisi dan khazanah keagamaan pun dipertanyakan ulang. Gender pun memasuki babak baru, yang para feminis menyebutnya dengan gelombang ketiga feminisme.

Keempat, gender sebagai pendekatan dalam studi agama. Masuknya isu gender dalam persoalan global, membuat para pengkaji agama membuktikan seberapa besar perhatian agama terhadap persoalan gender serta solusi atas problem tersebut. Namun secara lebih jauh, isu gender ini merupakan upaya untuk mempertemukan agama-agama.

Dari keterangan di atas secara sederhana bisa disimpulkan bahwa, kata gender bukanlah sekedar istilah tetapi sebuah konsep dengan kepentingan tertentu. Gender bukan hanya usaha untuk membedakan manusia secara biologis dan non-biologis, tetapi ia merupakan upaya untuk menggeser paradigma berpikir masyarakat terhadap sifat dan fungsi laki-laki dan perempuan, serta menolak pembagian peran berdasarkan biologis. Gender bukanlah kata tanpa makna, tetapi ia adalah sebuah gerakan lokal yang menjadi isu global dan dikaji menjadi suatu wacana kefilsafatan bahkan wacana keagamaan. Sehingga mengkritisi dalam setiap pemakaian istilah atau kata gender sangatlah diperlukan, terlebih lagi dalam mengadopsi pemahamannya. Gender bukanlah kata kosong, karena setiap kata berisi makna dan setiap makna mengandung konsep dan setiap konsep dihasilkan oleh worldview atau ideologi. ${ }^{8}$

Menurut Direktorat Pembinaan Pendidikan Masyarakat, Pendidikan Keluarga Berwawasan Gender (PKBG) adalah upaya penyadaran pemahaman hak dan kewajiban peran laki-laki dan perempuan untuk mewujudkan keadilan dan kesetaraan gender dalam keluarga. Sedangkan tujuannya untuk meningkatkan pengetahuan, pemahaman, wawasan, kesadaran dan kecakapan hidup, dalam berbagai hal, antara lain:

a. Perilaku adil dan setara gender terhadap laki-laki dan perempuan dalam keluarga.

b. Saling menghormati perbedaan dalam keberagaman dan menyelesaikan berbagai persoalan rumah tangga melalui dialog.

c. Kesadaran terhadap hal-hak dasar anak (perempuan dan laki-laki) khususnya di bidang pendidikan.

d. Melindungi kesehatan ibu dan anak, mencegah kematian ibu melahirkan dan bayi, mencegah penelantaran dan kekerasan terhadap anak dan memberikan perlindungan terhadap anak(marginal, terlantar, dan bermasalah dengan hukum).

e. Mencari alternatif pemecahan masalah pelanggaran HAM.

f. Penguatan kesejahteraan keluarga melalui pengelolaan ekonomi keluarga.

\footnotetext{
${ }^{7}$ Mohammad Muslih, Bangunan Wacana Gender. (Ponorogo: CIOS, 2017), 5-17.

${ }^{8}$ Hamid Fahmy Zarkasyi, Misykat: Refleksi tentang Westernisasi, Liberalisasi, dan Islam, (Jakarta: INSIST-MIUMI, 2012), xxvii.

${ }^{9}$ Direktorat Pembinaan Pendidikan Masyarakat, (Norma, Standar, Prosedur, danKriteria) Petunjuk Teknis Penyelenggaraan Program Pendidikan Keluarga Berwawasan Gender(PKBG) dan Tatacara Memperoleh Dana Bantuan Dari Direktorat Pembinaan PendidikanMasyarakat, Jakarta: Direktur Jenderal Pendidikan Anak Usia Dini, Nonformal, dan Informal,2014), 3.
} 
Keluarga adalah salah satu elemen pokok pembangunan entitas-entitas pendidikan, menciptakan proses-proses naturalisasi sosial, membentuk kepribadian-kepribadian, serta memberi berbagai kebiasaan baik pada anak-anak yang terus bertahan selamanya. Dengan kata lain, keluarga merupakan benih awal penyusunan kematangan individu dan struktur kepribadian. ${ }^{10}$ Keluarga adalah sebagai persekutuan hidup terkecil dari masyarakat dan negara luas. Pangkal ketentraman dan kedamaian hidup adalah terletak dalam keluarga. ${ }^{11}$

Diskursus tentang kekerasan terhadap perempuan dewasa ini, merupakan suatu hal yang menarik karena banyak diperbincangkan oleh kalangan praktisi, Lembaga Swadaya Masyarakat (LSM), akademisi dan masyarakat luas. Hal itu dilatarbelakangi adanya tuntutan peran perempuan yang semakin kompleks seiring dengan perkembangan zaman yang cenderung lebih memperhatikan Hak-Hak Asasi Manusia (HAM) tanpa melihat atau membedakan jenis kelamin.

Kekerasan terhadap perempuan merupakan tindakan pelanggaran HAM yang paling kejam yang dialami perempuan, oleh karenanya, tidak salah apabila tindak kekerasan terhadap perempuan tersebut oleh organisasi Perserikatan Bangsa-Bangsa (PBB) disebut sebuah kejahatan kemanusiaan.

Masuknya doktrin feminis dalam program pendidikan keluarga bukanlah tanpa risiko. Diawali dengan memisahkan sex(jenis kelamin) dengan gender, kemudian mempertanyakan peran laki-laki dan perempuan di masyarakat. Akan berlanjut pada keyakinan bahwa menjadi laki-laki dengan sifat-sifatnya serta menjadi perempuan dengan sifat-sifatnya adalah konstruksi dari sebuah budaya. Sehingga muncul anggapan bahwa, perempuan menjadi ibu rumah tangga adalah marginalisasi dan subordinasi, laki-laki sebagai pencari nafkah adalah stereotip dan violence dan jika perempuan yang bekerja maka itu adalah burden atau beban ganda. ${ }^{12}$

\section{Kesetaraan Gender Sebagai Tujuan Pendidikan Keluarga}

Kesetaraan gender yang menjadi tujuan pendidikan keluarga ini merupakan kelanjutan dari problem gender. Gender dan kesetaraan gender merupakan satu kesatuan paham atau ide yang tidak bisa dipisahkan. Pemisahan gender dengan sex (jenis kelamin) sebagai sesuatu yang relatif meniscayakan adanya usaha terhadap kesetaraan gender. Pengaruh utama gender di bidang pendidikan mengartikan kesetaraan gender sebagai kesamaan kondisi bagi laki-laki dan perempuan untuk memperoleh kesempatan dan hak-haknya sebagai manusia, agar mampu berperan dan berpartisipasi dalam kegiatan politik, ekonomi, sosial budaya, pertahanan, dan keamanan nasional. Sekilas pendefinisian ini terlihat bagus dan tanpa masalah. Namun, jika ditelusuri kesetaraan gender ini merupakan ide feminis yang bersumber pada pandangan hidup Barat, yaitu ide "gender equality." Ratna Megawangi menerangkan bahwa ide kesetaraan gender (gender equality) merupakan ide yang bersumber pada ideologi Marxis yang menempatkan

${ }^{10}$ Samsul Nizar, Pengantar Dasar-Dasar pemikiran Pendidikan Islam, Bandung: Remaja Rosda Karya: 2011), 125.

${ }^{11}$ M. Arifin. Hubungan Timbal Balik Pendidikan di Lingkungan Sekolah dan Keluarga (Jakarta:Bulan Bintang, 2015), 71.

${ }^{12}$ Mansour Fakih, Analisis Gender \& Transformasi Sosial..., 72-75. 
wanita sebagai kelas tertindas dan laki-laki sebagai kelas penindas. Paradigma Marxis melihat institusi keluarga sebagai musuh yang pertama-tama harus dihilangkan atau diperkecil perannya apabila masyarakat tanpa kelas ditegakkan, yaitu masyarakat yang tidak ada kaya-miskin, dan tidak ada perbedaan peran antar laki-laki dan perempuan. Ini dikarenakan keluarga dianggap sebagai cikal-bakal segala ketimpangan sosial yang ada, terutama berawal dari hubungan yang timpang antara suami dan istri. Sehingga bahasa yang dipakai dalam gerakan ide ini adalah bahasa baku yang mirip dengan gerakan ke kiri-kirian lainnya, seperti bagaimana mewujudkan kesetaraan gender melalui proses penyadaran bagi kaum tertindas, pemberdayaan kaum tertindas, perubahan struktural atau revolusi, dan penyebaran anti kaum patriak atau kaum borjuis. ${ }^{13}$

Kesetaraan gender merupakan agenda feminis meinstream. Tujuannya mewujudkan kesetaraan gender secara kuantitatif, yaitu pria dan wanita harus sama-sama berperan, baik di luar maupun di dalam rumah. Meski beberapa penemuan ilmiah dan pendapat terbaru yang menguatkan teori bahwa pria dan wanita memang secara alamiah, biologis, dan genetis berbeda namun para feminis masih percaya bahwa perbedaan peran berdasarkan gender adalah karena produk budaya, bukan karena adanya perbedaan biologis atau perbedaan nature. Sehingga tampak jelas bahwa, kesetaraan gender merupakan paham yang menyampingkan perbedaan manusia secara biologis. Hal ini berbenturan dengan pemahaman agama yang dalam menetapkan peran laki-laki dan perempuan tidak menyampingkan unsur biologis.

Oleh sebab itu definisi kesetaraan gender ini mendapat kritikan dari beberapa tokoh-tokoh agama. Di antaranya apa yang dikatakan Henri Shalahuddin "kondisi dan posisi laki-laki dan perempuan yang dipengaruhi oleh aspek biologis tidak dapat disetarakan. Kesetaraan berbeda dengan kesamaan. Kesetaraan 50-50 tidak bisa dicapai oleh negara mana pun. Semua agama membeda-bedakan posisi perempuan dan laki-laki, baik dari aspek biologis, maupun sosial."14 Tokoh lainnya adalah Adian Husaini, ia menerangkan bahwa paham kesetaraan gender adalah paham yang bernuansa kecurigaan dan kebencian. ${ }^{15}$ Senada dengan yang dikatakan Ratna, kesetaraan gender adalah istilah "suci" yang dalam tataran praktis hampir selalu diartikan sebagai kondisi "ketidaksetaraan" yang dialami oleh para wanita. ${ }^{16}$

Demikian halnya jika paham kesetaraan gender dipaksakan ke dalam institusi keluarga. Ia akan menuntut persamaan secara total bahkan mencoba menghapuskan aturan-aturan keluarga yang disandarkan kepada ajaran agama. Seperti apa yang pernah dituntut oleh beberapa kalangan feminis dalam Counter Legal Draft Kompilasi Hukum Islam. Di antaranya mengharamkan poligami, menghalalkan perkawinan beda agama, pernikahan dapat dilakukan tanpa wali, talak tidak hanya dijatuhkan oleh pihak laki-laki, dan lain sebagainya. Masa iddah bukan hanya dimiliki oleh wanita tetapi juga untuk laki-laki selama 130 hari. Hal

\footnotetext{
${ }^{13}$ Ratna Megawangi. Membiarkan Berbeda? Sudut Pandang Baru Tentang Relasi Gender, (Bandung: Mizan 2013), 11.

${ }^{14}$ Henri Shalahuddin, Indahnya Keserasian Gender dalam Islam, (Jakarta: KMKI, 2012), 9.

${ }^{15}$ Adian Husaini, “Kesetaraan Gender: Konsep dan Dampaknya Terhadap Islam.”ISLAMIA Jurnal Pemikiran dan Peradaban Islam Volume III, (Tahun 2010 No. 5), 13.

${ }^{16}$ Ratna Megawangi, Membiarkan Berbeda?..., 19,34
} 
ini tentu sangat bertentangan dengan ajaran agama Islam. Padahal ketentuan agama ini sangat adil dan melihat permasalahan secara menyeluruh baik secara biologis, psikologis, maupun sosiologis.

Dari pernyataan ini, menjadi semakin jelas bahwa, pembedaan konsep nature dan nurture atau kodrati dan bukan kodrati yang di gagas oleh para feminis, pada hakikatnya adalah keinginan perempuan untuk bisa bekerja di luar rumah, dan mencapai kesuksesan yang setara dengan laki-laki dalam hal materi. Sehingga bisa dikatakan, hanya untuk masalah materi para perempuan didorong agar menghilangkan sifat-sifat kewanitaannya bahkan sifat-sifat keibuannya sekalipun.

Dalam urusan dan peran anggota keluarga pun didasarkan pada aturan agama, misalnya aturan sebagai kepala keluarga adalah seorang laki-laki dan wanita sebagai ibu rumah tangga, seorang laki-laki boleh berpoligami atau beristri lebih dari satu sedangkan perempuan tidak boleh, seorang laki-laki berkewajiban mencari nafkah, dan menafkahi keluarga sedang perempuan berhak untuk mendapatkan nafkah dan lain sebagainya. Berdasarkan hal ini maka program pendidikan keluarga yang tidak ada di dalamnya unsur agama tidak cocok bagi masyarakat Indonesia.

Oleh sebab itu, bisa dipertimbangkan bahwa, pendidikan keluarga adalah pendidikan yang berwawasan agama dan life skills. Materinya pun sesuai dengan agamanya masing-masing. Misalnya dalam Islam, materinya menjadi komunikasi dalam Islam (muamalab), hak dan kewajiban anggota keluarga dalam Islam, pendidikan anak dalam Islam dan seterusnya. Dengan menghapus "demokrasi dan hak asasi" serta "kesetaraan dan keadilan gender" dari kolom konsep dasar. Dengan demikian bisa diharapkan terwujudnya tujuan keluarga yang bahagia berlandaskan agama, sebagaimana dalam Undang-Undang RI nomor 1 tahun 1974tentang perkawinan pasal 1, "Perkawinan ialah ikatan lahir batin antara seorang pria dengan seorang wanita sebagai suami-istri dengan tujuan membentuk keluarga (rumah tangga) yang bahagia dan kekal berdasarkan Ketuhanan Yang Maha Esa".

Dewasa ini kekerasan terhadap perempuan sangat mencemaskan, banyak kalangan terutama kalangan yang peduli terhadap perempuan. Walaupun sejak tahun 1993 sudah ada Deklarasi Penghapusan Kekerasan Terhadap Perempuan namun kekerasan terhadap perempuan tetap ada dan bahkan cenderung meningkat.

a. Diskriminasi dan Kekerasan terhadap Perempuan

Lahirnya Universal Declaration of Human Rights (UDHR) atau dikenal pula sebagai Deklarasi Umum Hak Asasi Manusia (DUHAM) yang disahkan Majelis Umum Perserikatan Bangsa-Bangsa (PBB) pada 10 Desember 1948 dan diikuti munculnya Konvensi Internasional tentang Hak-Hak Sipil dan Politik serta Ekonomi, Sosial, dan Budaya ternyata belum cukup memberi perlindungan secara terperinci mengenai hak asasi perempuan.

Oleh karena itu, pada tahun 1979 Majelis Umum PBB mengeluarkan Convention on the Elimination of All Forms of Discrimination Against Women (CEDAW) sebagai aturan yang membahas secara komprehensif mengenai 
hak asasi perempuan yang kemudian disetujui oleh negara-negara lain, termasuk Indonesia yang menandatangani konvensi tersebut pada Konferensi Sedunia Dasawarsa Perserikatan Bangsa-Bangsa bagi Wanita di Kopenhagen tanggal 29 Juli 1980. Setelah penandatanganan konvensi tersebut CEDAW di ratifikasi dalam hukum tertulis Indonesia melalui UU No. 7 Tahun 1984 tentang Pengesahan Konvensi mengenai Penghapusan Segala Bentuk Diskriminasi terhadap Wanita.

Dalam CEDAW diatur tentang prinsip persamaan (equality) dan anti diskriminasi yang perlu dijunjung, hak-hak sipil, politik, ekonomi, sosial, dan budaya perempuan yang harus didasarkan pada prinsip tersebut (misalnya hak untuk memilih dan dipilih, hak untuk bekerja, memperoleh pendidikan, dan kesehatan serta kesamaan di depan hukum) serta perlu dibangunnya sebuah komite yang bertugas untuk memantau dan melaporkan implementasi dari konvensi yang telah di ratifikasi ini.

Selain itu, secara eksplisit dalam aturan tersebut dapat dipahami yang dimaksud dengan diskriminasi terhadap perempuan ialah: setiap pembedaan, pengucilan atau pembatasan yang dibuat atas dasar jenis kelamin, yang mempunyai pengaruh atau tujuan untuk mengurangi atau menghapuskan pengakuan, penikmatan atau penggunaan hak-hak asasi manusia dan kebebasan-kebebasan pokok di bidang politik, ekonomi, sosial, budaya, sipil atau apapun lainnya oleh kaum perempuan, terlepas dari status perkawinan mereka, atas dasar persamaan antara laki-laki dan perempuan. ${ }^{17}$

Lebih jauh diskriminasi terhadap perempuan yang dimanifestasikan dalam bentuk kekerasan juga telah diatur upaya perlindungannya melalui UU Nomor 23 Tahun 2004 tentang Penghapusan Kekerasan Dalam Rumah Tangga (selanjutnya ditulis PKDRT). UU ini menjadi UU termutakhir yang dikeluarkan pemerintah untuk melindungi perempuan dari berbagai kasus kekerasan yang kian terjadi. Dalam UU tersebut telah diatur tentang penjelasan mengenai kekerasan dalam rumah tangga, pencegahan, perlindungan, dan pemulihan terhadap korban kekerasan serta ketentuan pidana untuk pelaku kekerasan.

Adapun yang dimaksud dengan kekerasan dalam rumah tangga dalam UU ini ialah: setiap perbuatan terhadap seseorang terutama perempuan, yang berakibat timbulnya kesengsaraan atau penderitaan secara fisik, seksual, psikologis, dan atau penelantaran rumah tangga termasuk ancaman untuk melakukan perbuatan, pemaksaan, atau perampasan kemerdekaan secara melawan hukum dalam lingkup rumah tangga.

1) Teori

Untuk menajamkan analisis tulisan ini akan digunakan beberapa teori yang relevan yaitu:

${ }^{17}$ Gerung, R, Hak. Asasi Manusia : Teori, Hukum, Kasus, (Jakarta: Filsafat UI Press, 2016), 37 
a) Teori Pemisahan Ruang Privat dan Ruang Publik

Menurut Nuri Suseno yang dimaksud dengan ruang privat ialah wilayah di mana individu berada dengan dirinya sendiri dan dengan individu lain yang mempunyai relasi intim dengannya, sedangkan ruang publik adalah wilayah dimana individu melakukan kegiatan dan berpartisipasi secara ekonomi, politik, dan sosial. Kedua konsep ruang ini pada dasarnya berada dalam tataran abstrak. ${ }^{18}$

Adapun tujuan dari dibuatnya pemisahan antara ruang privat dan ruang publik ialah untuk melindungi kebebasan individu dari intervensi para penguasa dan kekuasaan yang sewenang-wenang, dengan tujuan inilah, tradisi libertarian berusaha menjaga dan mempertahankan dikotomi publik dan privat.

Pemisahan ruang ini juga dimaksudkan untuk menjadikan wilayah privat sebagai sebuah wilayah yang aman dari perpanjangan tangan pemerintah dan tempat di mana banyak perempuan dapat melakukan oposisi terhadap wilayah publik yang sering kali terlalu di politisir, mengatur, dan memaksa. Meski ruang privat dan publik membentuk relasi oposisi biner, Irish Marion Young justru berpendapat bahwa pemisahan ranah publik dan privat dapat diterima selama tidak membentuk oposisi yang bersifat hierarkis, artinya wilayah publik tidak mendominasi wilayah privat dan secara absolut menunjukkan sisi yang berlawanan.

Menurutnya wilayah privat perlu dipahami sebagai aspek dari kehidupan laki-laki atau perempuan yang terlepas dari orang lain, hampir sama dengan Young, Ruth Lister berpendapat bahwa wilayah privat bukanlah wilayah yang diekslusikan dari institusi-institusi publik.

Wilayah ini adalah ruang dimana seseorang memilih untuk berada apabila dia hendak menarik diri dari pandangan orang lain, akan tetapi tujuan yang berusaha dicapai dari konsep separasi ruang ini justru menimbulkan dampak negatif. Pemisahan ruang privat dan publik telah menempatkan perempuan dalam posisi yang sangat lemah dan tidak berdaya karena perannya yang dipersempit hanya sebatas pada urusan domestik, perempuan dibebankan tugas sebagai pengurus rumah tangga dan pemelihara anak sebagaimana yang diharapkan dari peran gender-nya.

Dalam kondisi ini perempuan tidak terlindungi dari kemungkinan kesewenang-wenangan yang dilakukan oleh suami, ayah, atau pun saudara laki-lakinya dimana para lelaki yang memiliki hubungan dekat dengan perempuan tersebut mempunyai kekuasaan yang sangat besar dalam keluarga.

${ }^{18}$ Suseno, N, Kewarganegaraan : Tafsir, Tradisi, Dan Isu-Isu Kontemporer, (Depok, :Departeman Ilmu Politik FISIP UI, 2010), 65 
Dengan menggunakan kerangka pemisahan, maka sesungguhnya kebebasan individu yang hendak dilindungi dan dijaga melalui penerapan konsep ini tidak berlaku bagi perempuan, ${ }^{19}$ konsep dan praktik kewarganegaraan menurut tradisi libertarian gagal dalam melindungi perempuan dari opresi yang dialaminya di wilayah privat.

Carole Pateman (1988) melalui bukunya Sexual Contract berusaha menggambarkan kontrak sosial yang dibentuk dalam suatu pernikahan justru berubah menjadi kontrak seksual akibat pembagian kerja seksual (sexual division of labour) yang tidak seimbang dalam rumah tangga, Pateman mengkritik pemisahan ruang privat dan publik yang dinilainya bersifat patriarkal dan hanya menguntungkan laki-laki, perempuan yang memasuki pernikahan, didomestikkan dan didominasi melalui stereotip peran gender.

Lebih jauh hal ini dilanggengkan dengan legitimasi nilai patriarki yang semakin kuat dalam masyarakat karena ruang publik sepenuhnya dikuasai oleh laki-laki dan norma yang mereka buat, pemisahan ruang privat dan publik juga menjadikan peran dan tanggung jawab pemeliharaan yang dilakukan oleh perempuan di ranah privat tidak diperhitungkan di ruang publik.

Inilah yang dimaksud Derek Heater dengan mengatakan bahwa konsep ataupun praktek kewarganegaraan yang terjadi di wilayah publik secara samar menunjukkan berbagai bentuk opresi terhadap perempuan di wilayah privat, dengan dilakukan pemisahan, maka wilayah privat menjadi sebuah wilayah yang tidak relevan bagi kewarganegaraan. Perempuan menjadi kehilangan banyak hak sipilnya di ruang publik.

Munculnya beban ganda ketika perempuan kemudian ikut terlibat dalam urusan mencari nafkah juga turut menjadikan partisipasinya sebagai warga negara menjadi berkurang. Keadaan yang terjadi secara struktural ini telah menempatkan perempuan pada apa yang disebut sebagai warga negara kelas dua.

b) Teori Civil Death

Masih terkait dengan pembahasan teoritik di atas, Derek Heater, dalam bukunya $W$ ho is Citizen, menuliskan bahwa perempuan akan memasuki situasi civil death (kematian sipil) ketika mereka menandatangani kontrak perkawinan, ${ }^{20}$ artinya akan terjadi sebuah kondisi di mana perempuan yang telah menikah malah kehilangan hak-hak sipilnya sebagai warga negara karena perempuan tersebut berada di bawah subordinasi laki-laki.

Heater menyebutnya "civil death" dikarenakan di masyarakat berkembang suatu pandangan umum bahwa perempuan yang telah

\footnotetext{
${ }^{19}$ Suseno, N, Kewarganegaraan: Tafsir, Tradisi, Dan Isu-Isu Kontemporer, (Depok:Departeman Ilmu Politik FISIP UI, 2010), 76

${ }^{20}$ Heater, D, What Is Citizenship, (Cambridge:Polity Press, 2012), 106
} 
menikah tidak dapat lagi berpartisipasi sebagai warga negara dalam kegiatan publik; ia tidak tergolong sebagai warganegara yang bebas dan tidak memiliki hak-hak berpartisipasi sebagai warga negara. ${ }^{21}$

Bunyi konstitusi ini jelas mendukung pernyataan Heater yang menyebutkan adanya kematian sipil yang dialami oleh perempuan setelah menikah, dimasukkan atau disatukannya hak-hak istri dengan hak-hak suami menjadikan perempuan tidak lagi memiliki hak-hak legal setelah menandatangani kontrak pernikahan.

Perempuan menjadi kehilangan hak sipil dan hak pribadi untuk memiliki properti, alhasil terjadi subordinasi legal suami terhadap istri yang kemudian diperkuat dengan pernyataan John Stuart Mill yang menyatakan bahwa "tidak ada yang lebih budak daripada seorang istri dalam artian yang sesungguhnya" dan beberapa kelompok feminis bahkan menyatakan pernikahan sebagai white slave code karena kedudukan perempuan yang tetap tersubordinasi meski telah memasuki sebuah kontrak legal bernama pernikahan. ${ }^{22}$

Keistimewaan keluarga tidak lepas dari fungsinya yang besar dalam kehidupan manusia. Di antaranya fungsi afektif dan reproduksi, keluarga memberikan kasih sayang dan melahirkan keturunan. Fungsi religious, keluarga memberikan pengalaman dan pendidikan keagaman kepada anggota-anggotanya. Fungsi rekreatif, keluarga merupakan pusat rekreasi bagi anggotanya. Fungsi protektif, keluarga melindungi anggota-anggotanya dari rasa takut, khawatir, ancaman fisik, ekonomi, dan psikosional. Artinya keluarga merupakan tempat pemecahan masalah-masalah tersebut. Fungsi edukatif, keluarga memberikan nilai-nilai pendidikan kepada anggotanya, terutama anak-anak. Fungsi sosial, keluarga merupakan tempat latihan proses sosialisasi nilai-nilai yang berlaku dalam masyarakat kepada anggotanya. ${ }^{23}$

\section{PENUTUP}

Keseteraan gender bukan berarti mempertentangkan antara laki-laki dan perempuan. Akan tetapi lebih dimaknai pada upaya membangun relasi dan kesempatan yang sama antara laki-laki dan perempuan. Gender bukan sekedar istilah, tetapi sebuah konsep yang membawa misi, filosofi. dan ideologi feminisme Barat yang sarat dengan nilai-nilai kebebasan (liberty), persamaan (equality), relativisme, dan kebencian terhadap budaya patriaki. Ia bukan sekedar paham yang membedakan peran laki-laki dan perempuan secara biologis maupun non-biologis, melainkan sebuah upaya memarjinalkan nilai-nilai agama, dengan memisahkan aspek biologis dan peransosial. Gender bukanlah gerakan yang memperjuangkan nasib perempuan,

${ }^{21}$ Suseno, N, Kewarganegaraan: Tafsir, Tradisi, Dan Isu-Isu Kontemporer, (Depok: Departeman Ilmu Politik FISIP UI, 2010), 128

${ }^{22}$ Ibid., 130

${ }^{23}$ Didin Hafidhuddin, Keunggulan Keluarga Islami, Al-Insan: Jurnal Kajian Islam, Vol. 2, (Tahun 2006 No.3), 46. 
sebaliknya, ia merupakan gerakan yang menghapus naluri keibuan dari perempuan dengan memisahkan peran yang kodrati dan yang bukan kodrati. Tetapi justru sebuah keharmonisan dan keserasian. Namun, dengan paham kesetaraan gender, hal ini bisa berubah. Semua yang tidak sama dan tidak setara dianggap ketidakadilan dan penindasan. Bahkan paham ini pun akan selalu menuntut kesamaan dan kesetaraan, tanpa memahami bahwa, untuk menjadi adil tidaklah selalu setara dan untuk menjadi serasi tidaklah selalu sama.

Sehingga, gender bukan sekedar istilah tetapi sebuah doktrin feminis yang menghapuskan fitrah manusia. Kesetaraan gender adalah ungkapan manis yang penuh harapan dan impian namun ia hanyalah kezaliman dan kemustahilan sebagai sarana penerapan gender dalam keluarga "Engendering Families" bukanlah langkah pemberdayaan keluarga tetapi sebagai "Endangering Families" yang membahayakan institusi keluarga.

\section{DAFTAR PUSTAKA}

Anshor, M. U, “Kompilasi Hukum Islam yang Ramah terhadap Perempuan”, Jurnal Perempuan, Vol. 73, No. 28, 2012.

Beauvoir, Simone de. The Second Sex. New York:Vintage Press, 2011.

Gamble, S, Feminisme Dan Postfeminisme, Yogyakarta: Jalasutra, 2010.

Gerung, R, Hak Asasi Manusia : Teori, Hukum, Kasus, Jakarta: Filsafat UI Press, 2006.

Haryatmoko, Dominasi Laki-Laki Melalui Wacana In N. I. Subono, Feminis Laki-Laki : Solusi Atau Persoalan?, Jakarta: Yayasan Jurnal Perempuan 2001.

Hasyim, N, "Gerakan Laki-Laki Pro Perempuan : Transformasi Dua Sisi”, Jurnal Perempuan, Vol. 64 , No. 61, 2019.

Hendrya, P, Pemberdayaan Perempuan Korban Kekerasan Dalam Rumah Tangga (KDRT) Dalam Perspektif Ketahanan Individu Studi Kasus Perempuan Korban KDRT Klien P2TP2A DKI Jakarta, Depok: Universitas Indonesia, 2011.

Jurnal Perempuan, "Wawancara Musdah Mulia : Perempuan Dan Keluarga : Berawal Dari Kompilasi Hukum Islam”, Jurnal Perempuan, Vol. 73, No.3, 2012.

Komnas Perempuan, Catatan Tahunan 2012, Jakarta: Komnas Perempuan, 2012.

Megawangi, Ratna. Membiarkan Berbeda Sudut Pandang Baru Tentang Relasi Gender. Bandung: Mizan, 2015.

Murniati, A. N, Getar Gender : Perempuan Indonesia Dalam Perspektif Agama, Budaya, Dan Keluarga, Magelang: Indonesiatera, 2014.

Pengadilan Tinggi Banjarmasin, 2011, Putusan Pengadilan Tinggi Banjarmasin Nomor 67/PID.SUS /2011/PT.BJM, Banjarmasin, Kalimantan Selatan, Indonesia.

Pusat Studi Kajian Wanita, Feminist Method And Methodology, Jakarta: Program Studi Kajian Wanita, 2012.

Squires, J, Gender In Political Theory, Wiley, Blackwell, 2010.

Suseno, N, Kewarganegaraan : Tafsir, Tradisi, Dan Isu-Isu Kontemporer, Depok: Departeman Ilmu Politik FISIP UI, 2010. 
Zarkasyi, Hamid Fahmy. Misykat : Refleksi tentang Westernisasi, Liberalisasi, dan Islam. Jakarta: INSIST-MIUMI, 2012. 
